Title:

State-Society Trust in Sino-Brazilian Agriculture

Author:

Adrian H. Hearn

Address:

3007/187 Weston St,

Brunswick East,

VIC 3057, Australia

a.hearn@unimelb.edu.au

Bio:

Adrian H. Hearn is an Associate Professor and an Australian Research Council (ARC)

Future Fellow at the University of Melbourne and co-chair of the Latin American Studies Association (LASA) Section for Asia and the Americas. Examining China's impact on global governance and local lifeways, he has undertaken research in Brazil, Cuba, Mexico, Senegal, and China. Prof. Hearn's publications include Diaspora and Trust: Cuba, Mexico and the Rise of China (Duke University Press 2016), China Engages Latin America: Tracing the Trajectory (Lynne Rienner 2011), and Cuba: Religion, Social Capital, and Development (Duke University Press 2008). Email: a.hearn@unimelb.edu.au

Keywords:

China, Brazil, trust, food security, transparency 


\title{
State-Society Trust in Sino-Brazilian Agriculture
}

Adrian H. Hearn

\begin{abstract}
As Chinese cities edge toward projections of one billion residents by 2025, they are generating unprecedented demand for food. Ambitions to meet this demand with domestic production are still far from reality, prompting Chinese agriculture enterprises to buy and invest overseas. This article examines the consequences for Brazil, which in 2013 provided 45 per cent of China's soybean imports. It finds that diverging traditions of state-society trust have provoked Brazilian uncertainties about the objectives and management practices of investing Chinese actors. It concludes that successful "South-South" relations between China and Brazil will require fresh approaches to trust between state and society that break with previous development theory and practice.
\end{abstract}

\section{Introduction}

The National New-type Urbanization Plan envisions 60 percent of China's projected population of 1.43 billion living in cities by 2020, up from 53.7 percent when the plan was unveiled in March 2014 (Xinhua 2014). The broader goal is to underpin future economic growth with domestic consumption rather than exports, and in the process diminish investment's share of GDP from around 45 to 25 per cent. Augmenting the number of urban consumers is central to China's economic plan, and so therefore is the confidence of millions of citizens that they stand to benefit from suburban lifestyles. To maintain their trust the government must overcome a problem: the food necessary to sustain China's expanding cities is in short supply.

With only nine per cent of the world's arable land and a diminishing base of agricultural labor, China is exploring new strategies for producing and importing high-protein urban staples like beef, pork, chicken, and oil seeds. Acquisition of foreign agriculture products, particularly soybeans for human and livestock consumption, is therefore important to the viability of the Chinese government's vision of national economic development. 
Like their counterparts in the energy and mining industries, Chinese state owned enterprises (SOEs) in the agriculture sector have "gone out" to invest overseas. The foreign activities of SOEs such as COFCO, Heilongjian Beidahuang Nongken Group, Xinjiang Production and Construction Corps (XPCC), and Chongqing Grain Corp aim to augment food supply while stabilizing prices, which have proven no less volatile than other commodities.

A problem facing Chinese SOEs as they seek access to foreign agriculture is the emergence of legal barriers to their investments, driven in part by popular protest against Chinese "land grabs." Growers' associations in Latin America, Africa, and Australia contend that control of food production and land ownership are matters of national sovereignty, and should not be ceded to the boardrooms of foreign enterprises, much less those owned by the Chinese government. They also complain that Chinese enterprises insist on purchasing only primary products, for instance raw soybeans rather than processed or crushed soymeal or soy oil. This, they say, has entrenched a classic pattern of dependency on highly mechanized primary exports that fail to add value and generate employment. China therefore stands accused of "neocolonialism," relentlessly pursuing a "mercantilist approach" more than any concern for "win-win cooperation” (Camus et al. 2013:vii, also see Malena 2011:271272).

Brazil has become an epicenter of these tensions, having seen bilateral trade with China grow to $\$ 83.3 \mathrm{bn}$ in 2013 , largely due to the export of 33 million metric tons of soybeans (worth $\$ 17.2 \mathrm{bn}$ ) to China that year. China is Brazil's largest trade partner, and in 2013 Brazil provided 45 per cent of China's soybean imports, more than any other country. Not surprisingly, resulting debate in Brazilian policy circles revolves around the need to widen the scope of exports to China into higher valueadding sectors (Jenkins 2009, Jenkins and Freitas Barbosa 2012, Maciel and Nedal 2011). But Chinese investors have been slow to finance value-adding projects, raising doubts about their much-vaunted commitment to mutually beneficial "South-South cooperation." Unless Brazilian negotiators can steer inbound investment into higher segments of the agriculture value chain, soybeans will face the same booms, busts, and instabilities experienced by the mining sector over the past decade.

The above debates raise questions about trust between Chinese and Brazilian actors, and between governments and citizens within both countries. How do foreign agriculture investments build the confidence of Chinese citizens that their government 
is committed to their food security? How can China formulate reliable "South-South" relationships that offer partner countries more equitable outcomes than previous colonial and postcolonial experiences? How does Brazilian distrust of Chinese SOEs reinforce perceptions of imperiled national sovereignty, and vice-versa? The article frames these questions in the context of the literature on trust, noting key differences in Chinese and Brazilian traditions of state-society interdependence. It then explores the above questions and concludes that China's expanding global reach is bringing these diverging traditions into closer contact, generating both tensions and pressure for compromise.

\section{In government we trust}

Among the prominent works to theorize the intensifying strains of globalization is Samuel Huntington's (1996) Clash of Civilizations, which does so with mixed results. To his credit, Huntington recognizes that entrenched international conflicts over resources and territory have often been underpinned by opposing grand narratives of identity and progress. Less compelling are Huntington's scenarios of clash, which emphasize tensions directly between contending hegemons while paying less attention to proxy conflicts in third countries. China's global rise, particularly since the early 2000s, serves as a corrective not least because the contending influences of China, the United States, and Europe are most evident in middle-power nations such as Brazil and Australia. Both saw China become their main trading partner when the 2008-2011 Global Financial Crisis weakened U.S. demand for manufactured goods, directly affecting Brazilian exports and indirectly affecting Australia, which until then had relied mainly on U.S.-oriented Japanese manufacturers to buy its raw materials.

Civilizations, as Huntington rightly shows, are more than economic. The dynamics of capital are encompassed by political philosophies, norms of interaction, and modes of trust, and in these respects China's influence has been slower to expand. As in Australia, Brazilian structures of governance, planning, and exchange have been inherited from Europe and the United States. China's rise will not supplant these structural foundations, much less as the Chinese government attempts to integrate itself into the World Trade Organization, the IMF, the G20, and other bastions of global governance. These efforts constitute an assertive response to former U.S. Deputy Secretary of State Robert Zoellick's (2005) invitation for China to become a 
"responsible stakeholder" in "the international system that has enabled its success." U.S. politicians may have shaped the discourse on China's global socialization, but Brazil and the broader "global south" are the practical frontiers of this process.

Beijing's view of "South-South cooperation" exhibits important epistemological differences from established Western practice. As David Shambaugh (2008) observes, "for the Chinese, cooperation derives from trust-whereas Americans tend to build trust through cooperation." This is evident in China's 2008 Policy Paper on Latin America and the Caribbean, whose pursuit of a "harmonious world of durable peace and common prosperity" resembles previous policy papers on Europe and Africa. The paper pledges that, "the Chinese Government will...provide economic and technical assistance to relevant Latin American and Caribbean countries without attaching any political conditions" (MFA-PRC 2008). It does not, though, describe the mechanisms through which Chinese trade, aid, and investment might achieve this, nor how the management and regulation of these activities may support or conflict with European or North American approaches. Instead, it refers to the Five Principles of Peaceful Coexistence-unchanged since their establishment in 1954 to resolve a border dispute with India - to define the parameters of engagement. The Five Principles provide a general, hence adaptable, framework for international cooperation: mutual respect for territorial integrity and sovereignty, mutual nonaggression, non-interference in the internal affairs of other countries, equality and mutual benefit, and peaceful coexistence.

Chinese commentators have recently argued that the Five Principles reflect a Confucian perspective of nationhood and statecraft, particularly through their emphasis on consensual "harmonious" development, their pursuit of "holistic" outcomes, and their implicit advocacy of state stewardship over national and international affairs (Pan 2004, Wen 2004, Yang 2008). Although Confucius may have been coopted to legitimize contemporary policy, in practice the Five Principles demonstrate that "filial piety" premised on trust in the state remains a core tenet of Chinese politics.

Western political sociology also places a premium on trust, especially when it promotes cooperation between "those whom we don't know and who are different from us" (Uslaner 1999:124-125; Yamagishi and Yamagishi 1994; quotation in Armony 2004:21, also see Arrow 1974:26). Nan Lin describes trust as a public resource necessary for civic order: "Societies must have consensual rules and 
collective trust for them to function" (2001:148). Similarly, Francis Fukuyama argues that, "One of the most important lessons we can learn from an examination of economic life is that a nation's well-being, as well as its ability to compete, is conditioned by a single, pervasive cultural characteristic: the level of trust inherent in the society" (1995:7).

Chinese and Western scholars may agree that trust is a catalyst for prosperity and development, but their understandings of the state's impact on the formation of trust often diverge. Francis Fukuyama, for instance, warns that "legal apparatus" is a "substitute for trust" (1995:27). Commentator George F. Will offers a similar zerosum assessment of state intervention and trust: "as the state waxes, other institutions wane" (quoted in Skocpol 1996:20, also see Schambra 1994). For conservatives, the state's monitoring and compliance regulations incur cumbersome expenses and "transaction costs" while undermining the natural inclination of private actors to trust and cooperate with each other.

Not everybody agrees that trust is incompatible with state intervention. Kenneth Newton (2001:207) and Michael Woolcock (1998), for instance, emphasize the positive-sum nature of independent (horizontal) and state-society (vertical) trust. Similarly, Theda Skocpol finds that associational activity, entrepreneurial initiative, and the welfare state can reinforce each other in "close symbiosis" (1996:20). However, despite their opposing views, liberal and conservative scholars coincide in their insistence that the state must earn public trust through transparent governance (Fedderke et al. 1999, Moravcsik 2014). Consensus around this position is evident the post-Cold War "transparency revolution" that has shaped the good governance charters of practically every significant multilateral institution (Abbot and Snidal 2002, Goldsmith and Posner 2002, Leftwich 1993).

The rise of transparency as a normative principle has generated tensions with the Chinese government, whose insistence on the supreme authority of the Communist Party does not lend itself to public demands for openness. In the opinion of Sun Hongbo, a prominent commentator on Latin American affairs at the Chinese Academy of Social Sciences, "Western think tanks always point out that our foreign projects lack transparency. According to their understanding of transparency, we need to explain our policies in their way. In fact, our foreign policies have been deeply rooted in our culture, which includes respecting the leadership of the state. This is not easy for them to understand" (interview, 21 April 2010). To demand transparency of 
the Chinese government is, it seems, to challenge an ancient tradition of filial piety. Western insistence on transparency is also built on a political tradition, though one that recalls the birth of European democracy. Unlike Confucius, Zeus embodied Greek philosophy not by professing filial piety but by rejecting the overbearing command of his father, Cronus, and then castrating him (as Cronus had done to his own father, Uranus).

Embedded in these contrasting philosophies are diverging notions of trust in authority. The prior, built upon centuries of imperial rule, enjoins citizens to surrender personal prerogative to the Communist Party on the condition that the latter guarantee the "Three Benefits" of socialism. "The chief criterion for making that judgement," said Deng Xiaoping, "should be whether it promotes the growth of the productive forces in a socialist society, increases the overall strength of the socialist state and raises living standards" (Deng 1994). By contrast, early European political philosophy emphasized distrust of centralized power and the right of citizens to rebel against authoritarian rule. The legacy of this principle is present in 21 st century notions of good governance, a concept the United Nations premises on state responsiveness, participation, and transparency (UNESCAP 2011:3).

China's growing foreign influence has brought these distinct political philosophies into closer contact, engendering practical tensions that are becoming evident in global food production. As Alan and Josephine Smart write, agriculture is an "emotionally loaded" sector, infused with commitments to territorial sovereignty and cultural sensitivities "that are much more visceral, deeply held and more easily mobilized to justify restrictions than for other categories of commodities" (Smart and Smart, forthcoming). The disjuncture of top-down and bottom-up political philosophies manifests itself in uncertainty about the strategic objectives, management practices, and identities of investing Chinese enterprises. Thus, regulators around the world want answers to a deceptively simple question: who are the actors?

More transparent reporting on the part of Chinese firms would help to alleviate the concerns of food producers. So too, though, would recognition among the latter that working with Chinese investors will require them to understand a new set of guiding principles and organizational structures. Becoming "China literate," as former Australian ambassador to China Geoff Raby (2011) puts it, means learning not only about the legacies of imperial heritage, but also about episodes like the 1958-1961 
Great Famine and its aftermath. The Famine raised widespread doubts about the Communist Party's ability to manage national food production, but officially it has been defined as the "The Three Years of Natural Disasters" and reinterpreted under the "Mass Line Campaign" to downplay the number of deaths and legitimize absolute government stewardship over food security (Garnaut 2014, Wemheuer 2014). Basic awareness of Chinese history illuminates the political sensitivity of food production, as well as the reasons behind otherwise perplexing business practices, such as the tendency of Chinese SOEs to strike deals with foreign governments while overlooking the opinions of local nongovernmental actors. As community groups and civil rights associations around the world become more engaged with narratives of global governance, transparency, and responsiveness, such misunderstandings are becoming more common. Before considering the recent eruption of disputes in the Brazilian agriculture sector, let us first consider the Chinese government's efforts to build trust in its food security credentials at home.

\section{Bringer of harvests}

For 500 years prior to the 1911 overthrow of the Qing dynasty, Beijing's Temple of Heaven hosted a ceremony of paramount importance. Twice each year the Son of Heaven, as the emperor was known, petitioned for the empire's prosperity in the Hall of Prayer for Good Harvests (祈年殿). The public message was clear: entrust your food security to the supreme authority of the emperor. Divine intercession was backed up with earthly intervention, including sustained investments in flood protection and grain storage (Li 2007). Mencius, a disciple of Confucius, had argued that the emperor's authority to govern derived from his heavenly mandate, and that its loss would entitle citizens to rebel. Productive harvests demonstrated this mandate, and were therefore fundamental to the economic and political stability of the empire.

Food security remains central to the authority of China's 21 st leadership. To maintain economic growth at the rate necessary for current living standards and employment, the Chinese government is reorienting the economy to domestic urban consumption. To achieve this, Li Keqiang has projected the need to import some $\$ 10$ trillion worth of commodities by 2018 and invest $\$ 500$ billion overseas (Global Times 2013, WEF 2013). The prominent role of food in this calculus, and the state's 
assumption of responsibility over this process, is reflected in the China Development Bank's allocation of 200 billion RMB (\$32 billion) to finance agricultural development (including foreign investment) between 2012-2017.

Food is not a monolithic category; increasing the supply of one product can diminish demand for another. China's expanding meat imports, for instance, may eventually reduce demand for soy products and fish flour for domestic cattle rearing. The challenge facing Chinese planners is to identify an optimal mix of foreign and domestic inputs, and to gradually build national capacity to augment production of the latter. This tactic is evident in the National Development and Reform Commission (NDRC)'s Plan for Increasing National Grain Production Capacity by 50 Billion Kilograms (2009-2020). The Plan envisions 95 per cent coverage of China's grain demand through national production by 2020: "it is imperative to stick to the principle of basically achieving grain self-sufficiency domestically” (GAIN 2010:2).

China already produces 500 million metric tons of grains per year (including cereals, tubers, and pulses), but demand is projected to reach 572 million metric tons by 2020 (GAIN 2010:2). To address the shortfall, the NDRC has stressed the importance of technical upgrading. Its 2013 Report on the Implementation of the 2012 Plan for National Economic and Social Development notes that projects "for spreading agricultural technology were carried out in nearly all towns and townships," enabling the conservation of the nation's 121.3 million hectares of arable land, the earmarking of 106.7 million hectares for grain cultivation in 2013, and the production of "18.5 million tons of policy-supported grain for the year" (NDRC 2013:2,3). Technical efforts have focused on increasing yield through larger-scale irrigation, water conservation, upgraded pumping and drainage stations, and management of rivers to create new reservoirs and prevent floods (NDRC 2013:14). An accompanying goal is "to carry out major transgenic species development projects and accelerate research on new transgenic grain species" that are high-yield, multiresistant to disease, and tolerant of drought (GAIN 2010:23).

The NDRC's efforts have advanced Prime Minister Li's directive to build selfsufficiency in corn, rice, and wheat. Soybeans, though, remain an outlier. From ancient times until the Second World War, China (including Manchuria) produced more than 85 percent of the world's soybeans. But technological innovation in the United States and Latin America, and China's entry into the World Trade Organization, have led China to import ever-increasing quantities of this fundamental 
source of protein (Figure 1). Moreover, the crop's intensive use of land and water has led Chinese farmers to shift increasingly into corn production, which earns them $\$ 635$ per hectare more than soybeans (Xinhua 2013).

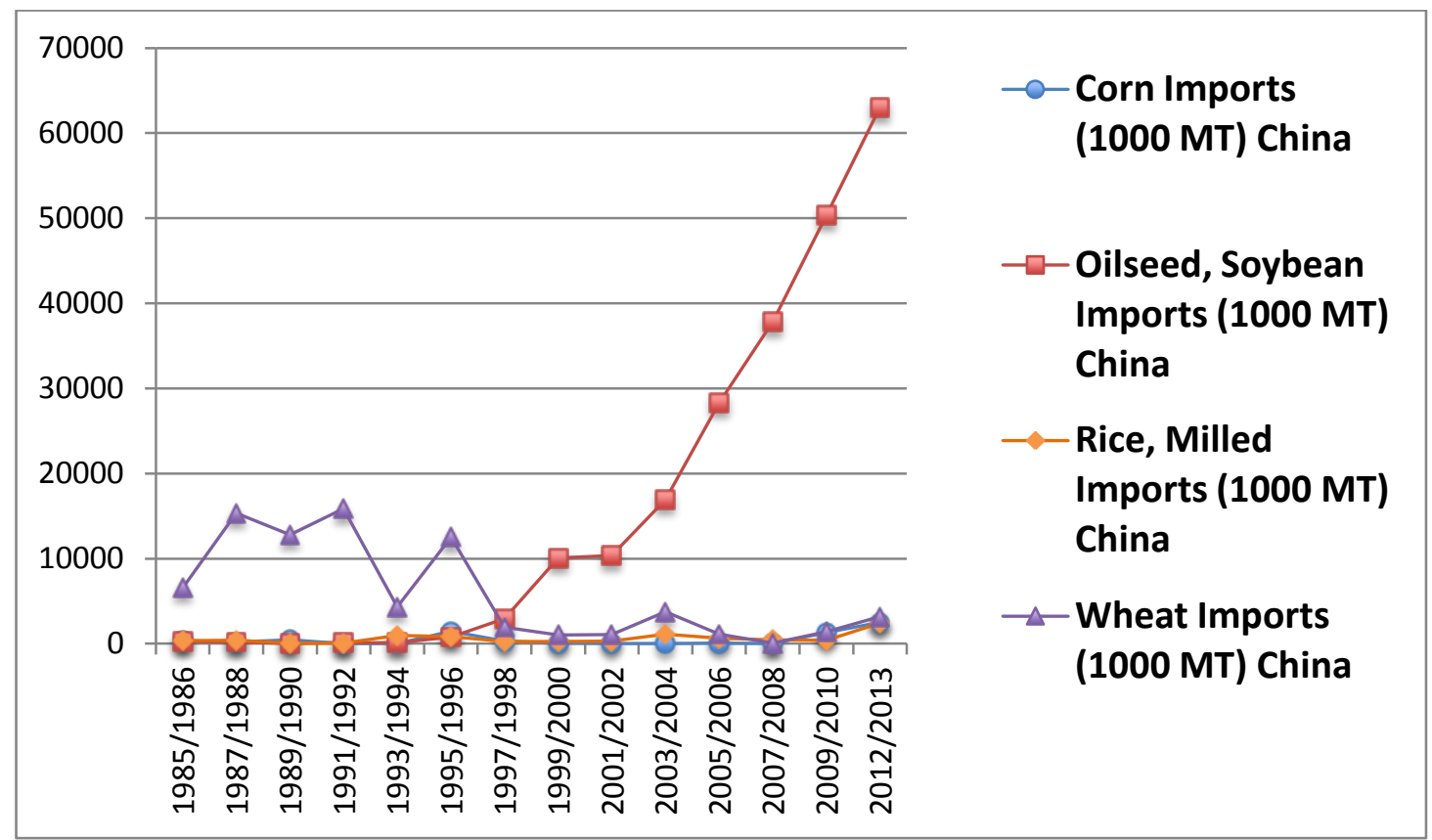

Figure 1. Chinese imports of basic food commodities. Source: USDA

Soybeans are a critical source of cooking oil and nutrition for China's urbanizing citizens, both directly and indirectly as feed in the pork production chain. However, reliance on imported soybeans raises challenges for Chinese planners, not least because of unstable pricing. IMF data show that the price of soybeans exhibited severe spikes in 2008 and 2011-2012, more than doubled from $\$ 217$ per metric ton in 2006 to $\$ 534$ in 2013, and slumped to $\$ 372$ in 2014 (IMF 2014). Such severe fluctuations complicate the ability of Chinese importers to harmonize budgets and storage with spikes and troughs in domestic demand. To sustain public confidence in its vision of greater consumption and more numerous and populous cities (and tolerance of the resulting inequalities), the Chinese government is attempting to bring the supply and pricing of food under control. As it has since ancient times, the Chinese leadership projects itself as the sole guarantor of the population's food security.

Investments in foreign soybean production advance the Chinese government's cause, and it must therefore build trust not only at home, but also overseas. As 
China's main supplier of raw soybeans, Brazil looms large in this challenge. Within Brazil, though, debate is intensifying about the motivations and potential disadvantages of Chinese investment. For instance, Brazilian ambitions to upgrade the agribusiness sector by attracting foreign capital into infrastructure, food processing, packaging, and other higher value adding segments of the food chain have generally not coincided with the focus of Chinese investors on primary production. The apparent disjuncture of Brazilian and Chinese objectives reflects misunderstandings on both sides, and as the next section shows, has generated Brazilian suspicions about the "neocolonial" designs of the Chinese state.

\section{Seeds of trust in Brazil}

Public debates in the Americas, Australia, Africa, and Eastern Europe reflect concerns that investing Chinese firms do not act independently, but rather in the service of the Chinese state, and therefore cannot be trusted to respect the rules of market competition. Whether or not such trepidations are justified is a matter of dispute among publics, scholars, and politicians. Some argue that the Chinese state, coherent in structure and unified in purpose, is the commanding actor behind frontline Chinese investors. A Congressional report by the U.S.-China Economic and Security Review Commission emphasizes the resulting threat to U.S. business:

Investments made by Chinese state-owned or -controlled companies can also pose economic security threats. The Chinese government provides significant financial and logistical support. This puts U.S. firms, which receive no such support, at a competitive disadvantage. When Chinese SOEs invest abroad, they do not necessarily seek profit and may instead pursue government goals such as resource acquisition or technology transfer...gaps exist in the U.S. government's ability to address the competitive challenges posed by SOEs (USCC 2013:106).

In Brazil, the Chairman of the China-Brazil Business Council, Sergio Amaral, has voiced similar preoccupations: “Sometimes you don't know whether the investments are looking for Brazil as a market or whether they correspond to strategic purposes of the Chinese government" (quoted in Pyne 2010). 
Others contend that Chinese firms, including SOEs, are independent actors that pursue their own agendas. Researchers have found that some Chinese SOEs in the minerals sector have exercised a high degree of operational discretion, in some cases — such as the Shougang Hierro iron ore mine in Peru-coming into conflict with administrators in China (Gonzalez-Vicente 2012, Guo et al. 2012). Former European Commissioner for Competition Policy, Joaquín Almunia, has tried to lower the heat in the dispute over Chinese SOE independence by focusing on the implications for competition rather than the identities of actors:

We look carefully at whether, through the State, companies in the same sector act as one or different entities. This is not because they are foreign or we have a prejudice against State control, but because it is a relevant aspect for assessing if competition will be significantly reduced or not (2011).

A 2013 deal struck by the Xinjiang Production and Construction Corps to buy three million hectares for grain and pork production in the Ukraine is often cited as evidence of the scale of investment that Chinese SOEs are willing and able to execute to advance their government's food security goals, often with little chance of turning a profit. The China-Brazil Business Council (CBBC) perceives an emerging regulatory challenge in this increasingly global phenomenon:

This issue is controversial in Brazil and other countries (Canada and Australia, particularly) and has led governments to take action. In this respect, it seems that a consensus is being formed: countries need strong legislation and institutions which can clearly distinguish and characterize opportunities and threats arising from the sale of land to foreign groups (CBBC 2011:26).

Uncertainty about the motivations and identities of the actors behind Chinese proposals to purchase or lease arable land have provoked some countries to impose legal barriers to impede inward investment from SOEs. In Argentina, a bid by Chinese firm Heilongjian Beidahuang Nongken Group Co. to acquire 320,000 hectares to grow soybeans in Río Negro province met with intense local protest. 
Argentina's Grupo de Reflexión Rural (Rural Reflection Group) argued that, "They [Chinese firms] are buying up and taking vast areas of land out of circulation to meet their own food and forage production demands" (GRR 2010). Public opposition led the Argentine congress to prohibit the deal from proceeding, and to set federal limits on foreign land ownership at 1,000 hectares (not exceeding 15\% of any property).

In Australia, Prime Minister Tony Abbott (then leader of the opposition Liberal-National Party) stated during a speech in Beijing in July 2012 that, "It would rarely be in Australia's national interest to allow a foreign government or its agencies to control an Australian business" (Grigg 2012). His party simultaneously published a pre-election Policy Paper on Foreign Investment in Australian Agricultural Land and Agribusiness. The paper expressed concern that, "the creeping cumulative acquisition of agricultural land...may be inconsistent with both the national interest and the interests of local communities," and that if elected, the Liberal-National Party would, "investigate options to strengthen the rules governing the sale of agricultural land and agribusinesses to foreign entities," including through the introduction of a land registry system (LNP 2012:3-4).

Similar concerns have emerged in Brazil, which in 2013 produced 88 million tons of soybeans, 33 million tons of which went to China. The massive scale of soybean exports has been accompanied by Chinese proposals to purchase, lease, or otherwise assume control of Brazilian arable land. Anxiety about this prospect is often expressed through websites, social media, and offhand remarks like that of former Brazilian Minister of Finance Antônio Delfim Netto that, "the Chinese have bought Africa and now they're trying to buy Brazil" (quoted in Powell 2011). Reported in mainstream media, Delfim's comment attracted broad support (e.g. Estadão 2010), prompting the federal government to formally revive a national land registry system and introduce a 5,000 hectare (and maximum 25 per cent) limit on foreign land investments. Brazilian researchers Rodrigo Maciel and Dani Nedal conclude that this legislation goes beyond the protection of national interests:

Sinophobia has also played a part in recent legislation limiting land purchases by foreign companies and individuals. Chinese FDI is said to be qualitatively different from that of traditional sources because of the controlled and opaque nature of the Chinese economy, China's selectivity in allowing inbound FDI, and the close association between 
investing companies and the Chinese state (Maciel and Nedal 2011: 250).

Chinese interest in acquiring arable land became a topic of national debate prior to Brazil's 2010 election. Sergio Amaral, Chairman of the China-Brazil Business Council (CBBC), argued that restrictions on Chinese finance were justified because they resemble China's own limits on inbound investment: "The Chinese are selective with the capital they let in. They don't accept every kind of investment. After the election, we should consider if the same shouldn't happen here" (quoted in Wentzel 2010). Benjamin Steinbruch, vice president of the São Paulo State Federation of Industries (FIESP), alleged that the Chinese government was attempting to control Brazilian assets, and that this constituted a challenge to national security (Rehder and Friedlander 2010).

These perspectives contrast with the earlier enthusiasm of Brazilian politicians and industry leaders toward Chinese finance during Hu Jintao's monumental 2004 Latin American tour, when international media reported his promise to invest $\$ 100$ billion in the region by 2010. Although Chinese newspapers reported that the figure referred to trade and not investment (e.g. China Daily 2004), President Lula Inácio Lula da Silva publicized the share of finance he had secured for Brazil, declaring that, "The awaited $\$ 7$ billion of Chinese investments in Brazil will help the country to regain its competiveness in strategic sectors such as infrastructure, energy, steel, and telecommunications" (quoted in Maciel and Nedal 2011:249). Between 2005 and 2013 Brazil received $\$ 31.4$ bn of Chinese investment, making it the fourth largest destination for Chinese finance after the United States, Australia, and Canada, but a decade after Hu's visit, this investment remains overwhelmingly focused on energy and metals (Heritage Foundation 2015).

The significance of Lula's declaration was not its misreading of Chinese intentions, but the reflection it provoked about the differences between value adding and resource seeking finance. This is a critical distinction for Brazil as the "mining boom" slows and opportunities for higher value-added exports-including in food production-emerge. The growing importance of agriculture to the Brazilian economy does not in itself ensure this transition, as it is driven mainly by raw soybean exports to China. The result, says the Foreign Ministry's Director of Agriculture and Basic Products, is overdependence on China: 
The fact that we send 48 percent of our soy to China is complicated because you have a clear dependence on one country. When this country decides it doesn't want to buy anymore of your soy, for whatever reason, you have a problem on your hands. Where is this excess of soy going to go? Who is going to consume it? Will we inundate the market? Will the price fall? What can be done? This dependency is very...it creates a certain instability (Orlando Ribeiro, interview, February 2013).

Notions of dependency have deep historical roots in Brazil, whose earlier colonization by Portugal and later relations with the United States entrenched a disadvantageous pattern of cheap commodity exports in return for expensive manufactured imports. The need to escape from this value-eroding predicament was the thrust of Raúl Prebisch's dependency theory, which led Brazil and most of its neighbors to pursue import-substitution industrialization — with mixed results — during the 1970s.

Elements of dependency theory continue to influence Brazilian public debate. As Selene Martínez Pacheco writes, "One of the common claims amongst the group that opposes Chinese influence in Brazil is that China is treating Brazil as a colony, taking Brazil's development backwards" (2014:118). FIESP is among several prominent institutions that perceives a deepening risk of overreliance on commodities, which between iron ore, oil, and soy, constitute 80 percent of Brazil's exports to China (Fellet 2011, Landim 2012a, Landim 2012b, Schneider 2012). The economy, say the critics, is overexposed not only to the volatility of commodity prices, but also to de-industrialization, since high exchange rates fuelled by resource exports between 2010 and 2014 undermined the competitiveness of national manufacturers. The impact of this "Dutch Disease" has allegedly been intensified by Chinese currency manipulation, which has artificially suppressed the price of Chinese manufactured exports and put Brazilian manufacturers out of business as cheap alternatives inundate the market.

Conscious of these critiques, Chinese officials have recognized the need to build trust in Brazil. China, they say, is empathetic toward Latin America's colonial past and acutely sensitive to the importance of industrial upgrading. Jiang Shixue, for 
instance, argues that China's relations with the region should be understood not as neocolonialism but as South-South cooperation because unlike colonial predecessors, China has inflated rather than depressed commodity prices and reduced rather than increased the price of manufactured products and capital goods. Furthermore, he writes, "while colonial powers sought to monopolize markets by discouraging the development of industries in their colonies, China invests actively in technology transfer programs, which have assisted the development of local industries across the continent" (Jiang 2011:62-63).

The Chinese government is pursuing two strategies to convince Brazilians that its vision of South-South cooperation can be trusted. One is to demonstrate willingness to invest in locally beneficial initiatives. An example of this is a soybean processing complex near the town of Barreiras, Bahia, which Chongqing Grain Corp agreed to build in 2010 . The proposed $\$ 300$ million project was to be the first of six facilities (totaling $\$ 2$ billion) that would crush soybeans to produce soymeal and soy oil, adding value in Brazil rather than in China. The plant would employ local workers, source soybeans from the immediate region around Barreiras, and reserve a proportion of the soy oil and meal it produced for the local market. By promising local benefit and added value, the project distinguished itself from previous colonial and post-colonial initiatives, and attempted to alleviate concerns about the negative implications of Chinese investment.

The mayor of Barreiras endorsed Chongqing's bid for 100,000 hectares of farmland and approved 100 hectares for the installation of the plant (CBBC 2011:26, Powell 2011). But Brazil's powerful landless rural workers' movement (MST) criticized the scale of the acquisition, joining a coalition of civil and environmental advocates to describe it as a land grab. Chongqing's status as a Chinese government enterprise deepened suspicions of its motives, reviving concerns that it may not act according to market principles. As the newspaper Estadão de São Paulo put it at the time, Chinese state owned enterprises "may act according to commercial interests, like other investors, but may follow the logic of a state - and not the Brazilian state" (Estadão 2010).

Brazilian anxiety, accompanied by federal limits on foreign land ownership, have bemused Chinese officials such as Zhang Dongxiang, CEO of the Bank of China's Brazil branch: "Public opinion sometimes seems to be against foreign investment... as if it makes local industry less competitive...these are some antiquated 
ideas" (quoted in Winter and Stauffer 2013). The Barreiras project was effectively shelved, having received approximately 15 percent of the projected $\$ 2$ billion by early 2015, and most of this in assessment and mapping activities.

In July 2014 Chinese president Xi Jinping also attempted to earn the trust of Brazilians by proposing to invest in locally beneficial infrastructure. A prominent feature of his $\$ 8.6$ billion package is a railway to transport soybeans and iron ore across Brazil and Bolivia to Peru's Pacific coast. Charles Tang, chairman of the Brazil-China Chamber Commerce, describes the project as mutually beneficial: "China has a strong interest in Brazilian commodities, so they want to invest in railroads in Brazil to reduce transport costs. This is a win-win situation, because the Brazilian government wants to attract investments in infrastructure" (quoted in Trevisani and Jelmayer 2014).

Despite the benefits that the Chinese railway and soy processing plant might bring to Brazil, these projects cannot avoid being associated with the interests of a foreign government. Chinese strategists have recognized that this association will inevitably tarnish the image of their SOEs, whatever local benefits they pledge. This predicament has provoked an alternative Chinese strategy: rather than building trust from scratch, buy existing stocks of it. Chinese enterprises are experimenting with this strategy in Latin America by scaling back their pursuit of land acquisitions and focusing instead on mergers and acquisitions that yield controlling stakes in established agribusiness networks. As early as 2008, researchers such as Bai Yimin of the Chinese Academy of Social Sciences noted the exemplary performance of Japan's Mitsui Foods, which gained access to Brazilian soy production in 2007 by acquiring 25 per cent of a Swedish company with a Brazilian subsidiary (Li 2008). Mitsui subsequently extended its coverage from production to logistics by purchasing shares in Brazilian farming companies that were already familiar to locals.

China's largest agriculture SOE, the China National Cereals, Oils and Foodstuffs Corporation (COFCO) implemented this strategy in 2014 with a $\$ 1.2$ billion deal to acquire 51 per cent of Dutch conglomerate Nidera, which has major agriculture holdings in Argentina, Brazil, and Eastern Europe. Four months later COFCO committed $\$ 1.5$ billion for 51 per cent of the agribusiness unit of Noble Group, a Singapore-listed commodities trader that operates grain warehouses and loading stations in Argentina, Brazil, Uruguay, and Paraguay, and five processing plants in Asia. Buying into locally trusted enterprises reduces COFCO's visible 
presence on the ground, and also helps Chinese buyers to circumvent the world's "Big Four" multinational grain brokers (Archer Daniels Midland, Bunge, Cargill, and Louis Dreyfus). By leaving Noble and Nidera's executive boards, administrative structures, and employment practices largely unchanged, COFCO has further diminished perceptions of Chinese economic aggression.

Hostile reactions to the agriculture investments of its SOEs have generated a range of measures from the Chinese government to overcome suspicion. Among these are high-level proposals to invest in value-adding infrastructure and bids acquire existing foreign enterprises. Such large-scale commitments demonstrate a shared recognition among policymakers in Beijing and Chinese SOEs operating overseas that successful foreign engagement requires both to build trust on the ground. In Brazil this task is complicated by the reluctance of citizens to trust their own government to guide economic development, let alone a foreign one. By contrast, the Chinese public expects its government to lead the way to national prosperity, international cooperation, and food security. These diverging appraisals of state leadership have inevitably clashed as the world's food exporters, in need of foreign investment to boost their productivity, entertain offers from Chinese investors. How, then, to progress from clash to compromise?

\section{Conclusion: the trust-transparency nexus}

From Asia to the Americas, and from Africa to Eastern Europe, Chinese SOEs are purchasing basic foods and investing in agriculture like never before. Increasing the food supply is fundamental to the Chinese government's vision of consumer-led national development. This vision aims to set in motion a new basis for both Chinese economic growth, and as Gordon Brown argued at London's 2009 G20 summit, international recovery from the global financial crisis. China's urbanization program is creating unprecedented opportunities for agriculture producers around the world, but their cooperation with Chinese customers and investors has been impeded by mutual ignorance of priorities and values.

The SOEs driving China's foreign engagement have been accused of everything from "land grabs" to poor ethical standards and disregard of community interests (Corrales et al. 2009; Eisenman 2006; Hanson 2008; Lam 2004; Santoli, Scheidel, and Shanks 2004). Their projects are seen to lack checks and balances 
because, as Cynthia Sanborne writes, "there are no incentives for Chinese leaders to take a stand on social and environmental responsibility" (quoted in Kotschwar et al. 2011). The Chinese state's preference for negotiating directly with foreign governments has also attracted accusations that it is enabling undemocratic regimes to avoid public disclosure of environmental impact and labor conditions (Caspary 2008, Ellis 2009, King 2009). China, it is argued, is spreading the message that "discipline, not democracy, is the key to development and prosperity" (CLATF 2006:21). In sum, China's difficulties establishing trust overseas result in large measure from inadequate transparency.

The above disputes suggest the need for strategies that integrate Chinese business practices into multilateral regimes of disclosure and governance, and that simultaneously adapt these regimes to the changing geopolitical landscape. A report from the U.S. Congressional Research Service acknowledges the resulting need for compromise, urging policymakers to "work harder to ensure that U.S. democratization and human rights values are not seen by other countries as encumbrances and prohibitions placed in the way of, but instead as things that ultimately will improve, their economic progress" (CRS 2008:15). Brazilian president Dilma Rousseff has also urged a softer public tone in relation to China, warning that "absurd xenophobia" will delay existing projects and impede new ones (Braga and Domingos 2013). Across the Pacific, Australian Prime Minister Tony Abbott adjusted his own earlier tone when he told a business convention in 2014 that, "We now appreciate that most Chinese state-owned enterprises have a highly commercial culture...They're not the nationalised industries that we used to have in Australia" (quoted in Kenny and Wen 2014).

The Chinese government is also becoming aware that it must adapt. In Brazil its SOEs have proposed value-adding investments in agricultural infrastructure that respond to local desires for skilled employment, new technologies, and economic diversification. These needs are becoming more pressing at a time when China's demand for primary products, together with an unrelenting inward flow of Chinese manufactured goods, are "taking away the ladder" under the pursuit of upgraded industries and value-added exports (Gallagher and Porzecanski 2010:57). Seeing these projects through is critical to the formation of trustworthy South-South relations that depart from prior colonial and post-colonial experiences. Chinese SOEs have also tried to offset their trust deficit by buying into existing multinational enterprises such 
as Noble Group and Nidera, which already own strategic infrastructure and territorial assets.

Recent Chinese projects may reduce tensions on the ground through adaptation and compromise, but they are yet to demonstrate greater transparency. Foreign criticism has instead elicited negative counter-reactions, such as the suggestion offered by Li Ruogu, President of the Export-Import Bank of China, that "Western countries should set an example in making public the resources they have grabbed in Africa in the past 400 years. Only after that can we come to the issue of China's transparency" (quoted in Ruan and Wu 2010).

Allegations aside, Li's appeal for historical reflection is warranted. Indeed, the deepest compromise facing China, Brazil, and the world may be to adapt longstanding traditions of state-society interaction to the 21 st century. The political heritage of Chinese SOEs does not dispose them to public scrutiny of their internal structures, deliberations, and priorities, but greater transparency is the surest way to diminish foreign concerns about their investments. The "Asian Century" will also require the world's agriculture exporters to reformulate established modes of interaction with the state. Since Chinese investors generally seek to engage foreign politicians as a prelude to cooperation with private actors, host country farmers will need to cultivate more trusting relationships with their provincial and federal governments in order to openly discuss local interests and concerns.

Diverging traditions of state-society trust, built over centuries, cannot quickly be reconciled. At their core are different views of political hierarchy, in one case espousing the indisputable leadership of the state and in the other the right of citizens to rebel. As Chinese investors "go out" overseas this disjuncture manifests in disputes over government accountability, theoretical debates about state intervention and trust, and trepidations that agriculture assets may come under the control of a neocolonial foreign government.

Fortunately, traditions do not determine behavior. As Marshall Sahlins (1981), Clifford Geertz (1973), and others have shown, they exist only insofar as actors appropriate them to advance their worldviews and interests. Opposing traditions of filial piety and civic defiance may respectively animate 21 st century demands for state supremacy and transparency, but both are susceptible to adaptation. If piety and defiance fail to serve their core purpose of building trust between state and society, they will be re-appropriated to support other agendas. Among these is the need for 
new forms of trust to accommodate China's rise, a process masterfully linked to historical tradition in Xi Jinping's articulation of The Chinese Dream (中国梦). Similarly, narratives of "deliberative" and "humble" democracy are gaining prominence both in China and among Western policy analysts to bridge past traditions of global hierarchy with more equitable visions of future integration. Acting behind the scenes in this unfolding drama are Confucius and Zeus. They are not natural allies, but they may yet share the stage.

\section{References}

Abbot, Kenneth W. and Duncan Snidal (2002) "Values and interests: international legalization in the fight against corruption." Journal of Legal Studies, vol.31, pp.141178.

Almunia, Joaquín (2011) "Recent developments and future priorities in EU competition policy." Speech to the International Competition Law Forum, St. Gallen, 8 April.

Armony, Ariel C. (2004) The Dubious Link: Civic Engagement and Democratization. Stanford: Stanford University Press.

Arrow, Kenneth (1974) The Limits of Organization. New York: W.W. Norton.

Braga, Juliana and Roney Domingos (2013) “"Toda xenofobia é burra', diz Dilma sobre crítica a chineses no pré-sal." G1 Rede Globo, 25th October.

<http://g1.globo.com/economia/noticia/2013/10/toda-xenofobia-e-burra-diz-dilmasobre-critica-chineses-no-pre-sal.html> (15 January 2015).

Camus, Juan Andrés; Jane LePham, Roshan Shankar, and Kenny White (2013)

Strictly Business? An examination of China's natural-resource acquisition strategy in Latin America. Report for the U.S. Government Accountability Office, Stanford: Stanford University. 
Caspary, Georg (2008) “China Eyes Latin American Commodities.” YaleGlobal Online, 18 January. <http://yaleglobal.yale.edu/content/china-eyes-latin-americancommodities> (14 January 2015).

CBBC (China-Brazil Business Council) (2011) Chinese Investments in Brazil: A new phase in the China-Brazil relationship. Rio de Janeiro: CBBC.

CLATF (China-Latin America Task Force) (2006) Findings and Recommendations of the China-Latin America Task Force-March-June. Miami: The University of Miami Center for Hemispheric Policy.

Corrales, Javier et al. (2009). Undermining Democracy: 21st Century Authoritarians. Washington, D.C.: Freedom House.

China Daily (2004). "Hu hails friendship with all Latin America." The China Daily, 14 November. <www.chinadaily.com.cn/english/doc/200411/14/content_391329.htm> (14 January 2015)

CRS (Congressional Research Service) (2008) China's Foreign Policy and 'Soft Power' in South America, Asia, and Africa, Committee on Foreign Relations of the United States Senate.

<https://www.fas.org/irp/congress/2008_rpt/crs-china.pdf > (15 January 2015)

Deng, Xiaoping (1994) “Excerpts from Talks Given in Wuchang, Shenzhen, Zhuhai and Shanghai, January 18-February 21 1992." In Selected Works of Deng Xiaoping, Vol. III (1982-1992). Beijing: Foreign Languages Press. <http://en.people.cn/dengxp/vol3/text/d1200.html> (7 April 2015)

Eisenman, Joshua (2006) "More Progress in Latin America; Jitters over U.S.-Japan Strategic Cooperation." China Reform Monitor, 613, Washington, D.C.: American Foreign Policy Council.

Ellis, R. Evan (2009) China in Latin America: The Whats and Wherefores, Boulder: Lynne Rienner. 
Estadão (2010) “China compra terras no Brasil”, Estadão de S. Paulo, $<$ http://opiniao.estadao.com.br/noticias/geral,china-compra-terras-no-brasil-imp,589697> (14 January 2015).

Fedderke, Johannes, Raphael de Kadt, and John Luiz (1999) "Economic Growth and Social Capital: A Critical Reflection.” Theory and Society 28(5):709-745.

Fellet, João. (2011) “Comercio Brasil-China bate recorde, mas peso de commodities preocupa governo.” BBC Brasil, 12 April.

<www.bbc.co.uk/portuguese/noticias/2011/04/110411_china_comercio_jf.shtml> (14 January 2015).

Fukuyama, Francis (1995) Trust: The Social Virtues and the Creation of Prosperity. New York: Free Press.

GAIN (Global Agricultural Information Network) (2010) National Plan for Expansion of Grain Production Capacity by 50 Billions Kilograms (2009-2020) [unofficial translation], Washington, D.C.: USDA Foreign Agricultural Service. Gallagher, Kevin P. and Roberto Porzecanski (2010) The Dragon in the Room: China and the Future of Latin American Industrialization. Stanford: Stanford University Press.

Garnaut, Anthony. 2014. "The Mass Line on a Massive Famine.” The China Story Journal, www.thechinastory.org/2014/10/the-mass-line-on-a-massive-famine/

Geertz, Clifford. 1973. The Interpretation of Cultures. New York: Basic Books.

Global Times (2013) "Chinese imports to hit $\$ 10$ trillion by 2018." The Global Times, 17 March, http://gbtimes.com/focus/economy/news/chinese-imports-hit-10-trillion2018 
Goldsmith, Jack L. and Eric A. Posner (2002) "Moral and Legal Rhetoric in International Relations: A Rational Choice Perspective." Journal of Legal Studies, vol.3, p.115.

Gonzalez-Vicente, Ruben (2012) "Mapping Chinese Mining Investment in Latin America: Politics or Market?” The China Quarterly 209, pp.35-58.

Grigg, Angus (2012) “Abbott warns China on takeovers.” The Australian Financial Review, July 24th.

GRR (Grupo de Reflexión Rural) (2010) “Colonias del Siglo XXI: alimentos, especulación y arrebato territorial." http://www.grr.org.ar/documentos/coloniasxxi.htm

Guo, Yingjie, Shumei Hou, Graeme Smith, and Selene Martinez Pacheco (2012) "Chinese outward direct investment: case studies of SOEs going global." In Law and Policy for China's Market Socialism, edited by J. Garrick, 131-143. New York: Routledge.

Hanson, Fergus (2008) The Dragon in the Pacific: More Opportunity than Threat." Sydney: the Lowy Institute for International Policy.

Heritage Foundation (2015) China Investment Tracker.

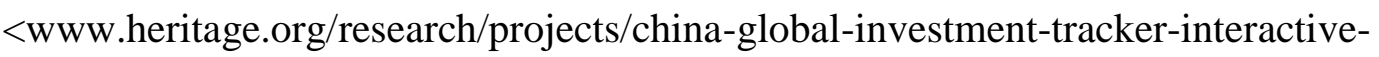
map> (14 January 2015).

Huntington, Samuel P. (1996) The Clash of Civilizations and the Remaking of World Order. New York: Simon \& Schuster.

IMF (International Monetary Fund) (2014) IMF Primary Commodity Prices database, http://www.imf.org/external/np/res/commod/index.aspx 
Jenkins, Rhys (2009) “The Latin American Case." In China and Latin America: Economic Relations in the 21st Century, edited by Rhys Jenkins and Enrique Dussel Peters, pp.21-63. Bonn: German Development Institute; Mexico City: CECHIMEX.

Jenkins, Rhys and Alexandre Freitas Barbosa (2012) "Fear for Manufacturing? China and the Future of Industry in Brazil and Latin America." The China Quarterly vol.209, 59-81.

Jiang, Shixue (2011) “Ten key questions.” In Adrian H. Hearn and José Luis LeónManríquez (editors) China Engages Latin America: Tracing the Trajectory. Boulder: Lynne Rienner, pp.51-65.

Kenny, Mark and Philip Wen (2014) "Tony Abbott briefs Xi Jinping on search for MH370" The Sydney Morning Herald, 11 April.

<www.smh.com.au/federal-politics/political-news/tony-abbott-briefs-xi-jinping-onsearch-for-mh370-20140411-zqtnj.html> (15 January 2015).

King, Royston (2009) "South-South Cooperation Should Be Set in a Framework of Good Environmental Governance.” Stabroek News, 25 September.

Kotschwar, Barbara, Theodore Moran and Julia Muir (2011) "Do Chinese Mining Companies Exploit More?” Americas Quarterly, Fall (November). <http://www.americasquarterly.org> (14 January 2015).

Lam, Willy (2004). “China's Encroachment on America's Backyard.” China Brief, 4, 23, Washington, D.C.: The Jamestown Foundation.

Landim, Raquel (2012a) “China freia e preço de minerio desaba." Estadao, 7 May. $<$ http://www.estadao.com.br/noticias/impresso,china-freia-e-preco-de-mineriodesaba-,869618,0.htm> (14 January 2015).

Landim, Raquel (2012b) “Dilma deveria ser mais rapida e agressiva.” Estadao, 7 May. <www.estadao.com.br/noticias/impresso,dilma-deveria-ser-mais-rapida-eagressiva-,869649,0.htm> (14 January 2015). 
Leftwich, Adrian (1993) "Governance, democracy and development in the Third World", Third World Quarterly vol.14, no.3, pp.605-624.

Li, Lilian. 2007. Fighting Famine in North China. Stanford: Stanford University Press.

Li, Ping. (2008) "Hopes and strains in China's oversea farming plan.” Economic Observer Online no. 374, 3 July.

<www.eeo.com.cn/ens/Industry/2008/07/03/105213.html> (14 January 2015).

Lin, Nan (2001) Social Capital: A Theory of Social Structure and Action. Cambridge: Cambridge University Press.

LNP (Liberal-National Party) (2012) Policy Paper on Foreign Investment in Australian Agricultural Land and Agribusiness. Canberra: Liberal-National Party.

Maciel, Rodrigo and Dani K. Nedal (2011) “China and Brazil: Two Trajectories of a 'Strategic Partnership.”' In Adrian H. Hearn and José Luis León-Manríquez (eds.), China Engages Latin America: Tracing the Trajectory, 235-255. Boulder: Lynne Rienner.

Malena, Jorge Eduardo (2011) "China and Argentina: Beyond the Quest for Natural Resources," in Adrian H. Hearn and José Luis León-Manríquez, China Engages Latin America: Tracing the Trajectory. Boulder: Lynne Rienner Publishers, pp. 257-278.

Martínez Pacheco, Selene (2014) Chinese 'Loan-for-Oil Deals in Brazil, Venezuela and Ecuador: Local Concerns and Perceptions. Ph.D. thesis, Faculty of Arts and Social Sciences, the University of Technology Sydney.

Ministry of Foreign Affairs of the People's Republic of China (MFA-PRC) (2008)

China's Policy Paper on Latin America and the Caribbean, online:

<http://www.gov.cn/english/official/2008-11/05/content_1140347.htm> (14 January 2015). 
Moravcsik, Andrew (2014) Trust, but Verify: The Transparency Revolution and Qualitative International Relations. Security Studies, 23(4):663-688.

NDRC (National Development and Reform Commission) (2013) Report on the implementation of the 2012 Plan for National Economic and social Development and on the 2013 Draft Plan for national Economic and Social Development. Beijing: NDRC.

Newton, Kenneth (2001) “Trust, Social Capital, Civil Society, and Democracy." International Political Science Review 22 (2): 201-214.

Pan, Tao (2004) “Timeless Theme of International Relations," Beijing Review 47 (23), 10 June.

Powell, Dawn (2011) “The Dragon’s Appetite for Soy Stokes Brazilian Protectionism." The Financial Times, 10 October.

Pyne, Solana (2010) “China’s Brazilian shopping spree”, The Global Post, 22 November, <www.globalpost.com/dispatch/brazil/101118/china-foreign-investment-trade> (14 January 2015).

Raby, Geoff. 2011. "What Does It Mean to be China Literate?” Speech by Dr. Raby, Australian Ambassador to China, to the Australian Institute of Company Directors Conference, Beijing, May 18, http://www.china.embassy.gov.au/bjng/ambo110518.html

Rehder, Marcelo and David Friedlander (2010) "E preciso restringir o investimento chines no Brasil." O Estado de Sao Paulo, 22 August, $<$ http://www.estadao.com.br/noticias/impresso,e-preciso-restringir-o-investimentochines-no-brasil,598482,0.htm> (14 January 2015). 
Sahlins, Marshall. 1981. Historical Metaphors and Mythic Realities. Ann Arbor: University of Michigan Press.

Santoli, Al, Miki Scheidel, and Lisa Marie Shanks (2004), "Beijing uses a 'weiqi' strategy in the Americas." China Reform Monitor, 562, Washington, D.C.: American Foreign Policy Council.

Schambra, William (1994) "By the People: The Old Values of the New Citizenship." Policy Review (Summer): 32-38.

Schneider, Carlos Rodolfo (2012) "Miopias do modelo de desenvolvimiento." $O$ Estado de Sao Paulo, 5 May. <www.estadao.com.br/noticias/impresso,miopias-domodelo-de-desenvolvimento-,868987,0.htm> (14 January 2015).

Skocpol, Theda (1996) “Unraveling from Above.” The American Prospect 7 (25): 2025 .

Shambaugh, David (2008) “China's New Foray into Latin America.” YaleGlobal, November 17, online: <http://yaleglobal.yale.edu/content/china\%E2\%80\%99s-newforay-latin-america> (14 January 2015).

Smart, Alan and Josephine Smart (forthcoming) "China, food security, and the TransPacific Partnership", in Adrian H. Hearn and Margaret Myers (eds.) China and the Future of Trans-Pacific Integration.

Trevisani, Paulo and Rogerio Jelmayer (2014) “China Looking to Play Larger Role in Funding Brazil's Infrastructure.” The Wall Street Journal, 13 July.

<www.wsj.com/articles/china-looking-to-play-larger-role-in-funding-brazilsinfrastructure-1405288036> (14 January 2015).

UNESCAP (United Nations Economic and Social Commission for Asia and the Pacific) (2011) What is Good Governance?, online:

<www.unescap.org/pdd/prs/ProjectActivities/Ongoing/gg/governance.asp> (14 January 2015). 
Uslaner, Eric M. (1999) “Democracy and Social Capital.” In Democracy and Trust, edited by Mark E. Warren, 121-150. Cambridge: Cambridge University Press.

Ruan, Victoria and J. R. Wu (2010) "Chinese Bank Defends Record in Africa." The Wall Street Journal, 8 March.

<www.wsj.com/articles/SB10001424052748704706304575107593721919622> (7 April 2015).

WEF (World Economic Forum) (2013) "Premier Li Keqiang Predicts Smooth Sailing for Chinese Economy", 12 September.

Wemheuer, Felix (2014) Famine Politics in Maoist China and the Soviet Union. New Haven: Yale University Press.

Wen, Jiabao (2004), Carrying Forward the Five Principles of Peaceful Coexistence in the Promotion of Peace and Development, 28 June, online: <www.fmprc.gov.cn/eng/topics/seminaronfiveprinciples/t140777.htm> (14 January 2015).

Wentzel, Marina (2010) "Brasil deve fomentar cooperação e evitar controvérsias com a China, dizem analistas," BBC Brazil, 17 November, <www.bbc.co.uk/portuguese/noticias> (14 January 2015).

Winter, Brian and Caroline Stauffer (2013) "Insight: Chinese investors sour on Brazil, and projects melt away." Reuters, November 1st.

Woolcock, Michael (1998) "Social Capital and Economic Development: Toward a Theoretical Synthesis and Policy Framework." Theory and Society 27:151-208.

Xinhua (2013) “China's over-reliance on foreign soybeans worries farmers.” Xinhua Insight, 16th March.

Xinhua (2014) “China unveils landmark urbanization plan,” Xinhuanet, 16 March, 
<http://news.xinhuanet.com/english/china/2014-03/16/c_133190495.htm> (9

February 2014).

Yamagishi, Toshio, and Midori Yamagishi (1994) "Trust and Commitment in the United States and Japan.” Motivation and Emotion 18(2):129-166.

Yang, Zhimin (2008) "Technological and Cultural Exchanges: Tightening the Link between China and Latin America", paper presented at the symposium China and Latin America: The New Face of South-South Cooperation, University of Technology Sydney, 3 December.

Zoellick, Robert B. (2005) Whither China: From Membership to Responsibility? Speech by Deputy Secretary of State Robert B. Zoellick to the National Committee on U.S.-China Relations, 21 September, online: <www.ncuscr.org/files/2005Gala_RobertZoellick_Whither_China1.pdf> (14 January 2015). 


\section{University Library}

\section{- M M I N E R VA A gateway to Melbourne's research publications}

Minerva Access is the Institutional Repository of The University of Melbourne

Author/s:

HEARN, A

Title:

State-Society Trust in Sino-Brazilian Agriculture

Date:

2015

Citation:

HEARN, A. (2015). State-Society Trust in Sino-Brazilian Agriculture. Journal of Chinese Political Science, 20 (3), pp.301-317. https://doi.org/10.1007/s11366-015-9364-0.

Persistent Link:

http://hdl.handle.net/11343/282689 